\title{
EFEKTIFITAS PERATURAN MAHKAMAH AGUNG TENTANG PROSEDUR MEDIASI TERHADAP PERAN MEDIATOR DI PENGADILAN AGAMA SIDOARJO
}

\author{
Achmad Syaifudin
}

\author{
SMP IT Darul Fikri Sarirogo 14/03 Sidoarjo. Email: \\ Didayn.Crotd@Gmail.Com
}

\begin{abstract}
This paper intends to compare the effectiveness of Supreme Court Regulation no. 1 of 2008 and Supreme Court Regulation no. 1 of 2016 about mediation procedures to mediators' role in Religious Court of Sidoarjo. By the documentation and interview techniques, this paper found that mediators in the Religious Courts of Sidoarjo became a facilitator in solving problems or disputes to reach favorable agreement for the parties. There is a difference between Perma No. 1 of 2008 with Perma No. 1 of 2016, namely the shorter duration of mediation, the obligation for the parties to attend directly the mediation meeting, and the existence of rules of good faith in the mediation process and its legal consequences. These differences are quite helpful in facilitating the mediation process, but there is no significant change in success rate prevention of divorce due to lack of good faith from the litigants. The Sidoarjo Religious Court should socialize Perma No. 1 of 2016 on mediation procedures to mediators and the parties of the dispute. Mediators in the Religious Courts of Sidoarjo should understand and apply correctly the existing rules in Perma No. 1 of 2016 on Mediation Procedures.
\end{abstract}

Keywords: Supreme Court Regulation No.1 of 2008 and Supreme Court Regulation No.1 of 2016

\begin{abstract}
Abstrak: tulisan ini bermaksud membandingkan Efektifitas Peraturan Mahkamah Agung No. 1 Tahun 2008 dan Peraturan Mahkamah Agung No. 1 Tahun 2016 Tentang Prosedur Mediasi terhadap peran mediator di Pengadilan Agama Sidoarjo. Dengan menggunakan teknik dokumentasi dan wawancara, tulisan ini menemukan, bahwa mediator di Pengadilan Agama Sidoarjo menjadi fasilitator dalam menyelesaikan masalah atau sengketa untuk mencapai kesepakatan yang menguntungkan pihak-pihak yang bersengketa. Terdapat perbedaan antara Perma No. 1 tahun 2008 dengan Perma No. 1 tahun 2016, yaitu mengenai batas waktu mediasi yang lebih singkat, adanya kewajiban bagi para pihak untuk menghadiri secara langsung pertemuan mediasi, dan adanya aturan tentang iktikad baik dalam proses mediasi serta akibat hukumnya. Perbedaan tersebut cukup membantu melancarkan proses mediasi, tetapi tidak ada perubahan tingkat keberhasilan yang siginifikan terhadap pencegahan terjadinya perceraian karena tidak adanya iktikad baik dari para pihak yang berperkara. Seyogyanya Pengadilan Agama Sidoarjo mensosialisasikan Perma No. 1
\end{abstract}

AL-HUKAMA

The Indonesian Journal of Islamic Family Law Volume 07, Nomor 02, Desember 2017; ISSN:2089-7480 
Achmad Syaifuddin: Studi Komparasi Efektivitas Perma...

tahun 2016 tentang prosedur mediasi kepada mediator dan para pihak yang bersengketa. Mediator di Pengadilan Agama Sidoarjo hendaknya memahami dan menerapkan secara benar aturan yang ada di Perma No. 1 tahun 2016 tentang Prosedur Mediasi.

Kata Kunci: Peraturan Mabkamah Agung No.1 Tabun 2008, Peraturan Mabkamah Agung No.1 Tabun 2016 Tentang Prosedur, Mediasi dan Peran Mediator

\section{Pendahuluan}

Konflik atau sengketa dapat saja terjadi dalam wilayah publik (pidana) maupun dalam wilayah privat (perdata). Konflik dalam wilayah publik terkait dengan kepentingan umum, di mana negara berkepentingan untuk mempertahankan kepentingan umum tersebut. Sedangkan hukum privat (perdata) menitikberatkan pada kepentingan pribadi, meliputi hukum keluarga, kewarisan, kekayaan, hukum perjanjian dan lain-lain.

Seiring perkembangan zaman, setiap pola hukum selalu dikembangkan oleh manusia untuk menyelaraskan kebutuhan yang dihadapi tanpa merubah prinsip yang telah ada. Mediasi adalah cara penyelesaian sengketa melalui proses perundingan untuk memperoleh kesepakatan para pihak dengan dibantu oleh mediator.1 Syahrizal Abbas memberikan definisi, bahwa mediasi dapat membawa pihak mencapai kesepakatan tanpa merasa ada pihak yang menang atau kalah (win-win solution).2 Upaya untuk mencapai win-win solution itu ditentukan oleh beberapa faktor diantaranya:

1. Proses pendekatan yang obyektif terhadap sumber sengketa yang lebih dapat diterima oleh pihak-pihak dan memberikan hasil yang menguntungkan. Dengan catatan, bahwa pendekatan itu harus menitikberatkan pada kepentingan yang menjadi sumber konflik dan bukan pada posisi atau kedudukan para pihak. Apabila kepentingan yang menjadi fokusnya, pihak-pihak akan lebih terbuka untuk berbagai kepentingan. Sebaliknya, jika tekanannya

1 Perma No. 1 Tahun 2016.

2 Syahrizal Abbas, Mediasi Dalam Hukum Syari'ah, Hukum Adat \& Hukum Nasional (Jakarta: Prenada Media Group, 2009), 17. 
pada kedudukan, para pihak akan lebih menutup diri karena hal itu menyangkut harga diri mereka.

2. Kemampuan yang seimbang dalam proses negosiasi atau musyawarah. Perbedaan kemampuan tawar-menawar akan menyebabkan adanya penekanan oleh pihak yang satu terhadap yang lainnya.3

Penyelesaian perkara melalui perdamaian dalam bentuk mediasi mempunyai berbagai keuntungan substansial dan psikologis, antara lain sebagai berikut: Penyelesaian bersifat informal, para pihak sendiri yang menyelesaikan sengketa, jangka waktu penyelesaian pendek, biaya ringan, aturan pembuktian tidak perlu, proses penyelesaian bersifat konfidensial (rahasia), hubungan para pihak bersifat kooperatif (kerja sama), hasil yang dituju samasama menang, bebas emosi dan dendam.4

Keberhasilan mediasi, menurut Gary Goodpaster yang dikutip oleh Bambang Sutyoso, terletak pada beberapa hal, antara lain: Para pihak mempunyai kekuatan tawar menawar yang sebanding, para pihak menaruh perhatian terhadap hubungan masa depan dan para pihak tidak memiliki permusuhan.5

Mediasi tidak akan pernah terjadi tanpa adanya peran mediator, sebagai pihak ketiga atau juga disebut penengah. Mediator mempunyai peranan penting, yaitu merumuskan, mengajak pihak berpekara agar dominan terlibat langsung dalam pencapaian kesepakatan tersebut. Tentu dengan setiap kelebihan, kesanggupan, ketrampilan, dan jam terbang dari mediator itu sendiri yang secara khusus membedakan antara mediator satu dan lainnya.

Ketentuan mengenai mediasi di pengadilan diatur dalam Perma No. 1 Tahun 2008 Tentang Prosedur Mediasi di Pengadilan. Perma ini menempatkan mediasi sebagai bagian dari proses penyelesaian perkara yang diajukan para pihak ke pengadilan. Hakim tidak secara langsung menyelesaikan perkara melalui proses peradilan (litigasi), tetapi harus terlebih dahulu mengupayakan

3 Maria S.W, et al., Mediasi Sengketa Tanah (Jakarta: KOMPAS Media Nusantara, 2008), 4.

4 Yahya Harahap, Hukum Acara Perdata (Jakarta: Sinar Grafika, 2006), 236.

5 Bambang Sutiyoso, Alternatif Penyelesaian Sengketa (Yogyakarta: Gama Mediasi, 2008), 60-61. 
mediasi. Mediasi menjadi suatu kewajiban yang harus ditempuh hakim dalam memutuskan perkara di pengadilan.6

Mediasi pada pengadilan memperkuat upaya damai sebagaimana yang tertuang dalam hukum acara pasal 130 HIR (Het Herziene Indonesische Reglement) atau pasal $154 \mathrm{Rbg}$ (Rechtreglement Buiten Gewesten). 7 Hal ini ditegaskan dalam pasal 2 Perma No. 1 tahun 2008, yaitu semua perkara perdata yang diajukan di pengadilan tingkat pertama wajib untuk mengikuti mediasi, dan merupakan pelanggaran yang mengakibatkan putusan batal demi hukum apabila tidak menempuh prosedur mediasi.s Tetapi pada kenyataannya, mediasi yang dilakukan selama ini dirasa tidak berhasil dan sangat sedikit mediasi yang dikatakan menempuh jalan damai seperti tujuan Perma No. 1 tahun 2008.

Untuk itu, Mahkamah Agung menerbitkan Perma No. 1 tahun 2016 tentang prosedur mediasi di pengadilan dengan tujuan menyempurnakan Perma No. 1 Tahun 2008 Tentang Prosedur Mediasi di Pengadilan. Penyempurnaan tersebut dilakukan Mahkamah Agung karena dalam Perma No. 1 tahun 2008 ditemukan beberapa masalah, sehingga penerapan mediasi di pengadilan tidak efektif. Mahkamah Agung menyadari, bahwa Perma No.1 tahun 2008 terdapat kendala-kendala dalam implementasinya, seperti tidak adanya kewajiban bagi para pihak untuk menghadiri secara langsung pertemuan mediasi dan kurang komplitnya peraturan yang lain, sehingga dapat dikatakan tidak berhasil sebagaimana yang semula diharapkan. Selain itu, sebab lainnya adalah karena tidak adanya i'tikad baik para pihak untuk menghadiri proses mediasi.9

Oleh karena itu, perlu dilakukan pengkajian lebih lanjut untuk memperoleh hasil yang lebih maksimum. Berdasarkan alasan tersebut, maka Mahkamah Agung melakukan penelitian dan

6 Syahrizal Abbas, Mediasi dalam Perspektif Hukum Syariah, Hukum Adat, dan Hukum Nasional (Jakarta: Kencana, 2009), 301.

7 Sarwono, Hukum Acara Perdata Teori dan Praktik (Jakarta: Sinar Grafika,2011), 159.

8 Mahkamah Agung RI, Perma RI No. 1 Tahun 2008 Tentang Prosedur Mediasi di Pengadilan MA RI.

9 Susanti Adi Nugroho, Mediasi Sebagai Alternatif Penyelesaian Sengketa (Jakarta: PT. Telaga Ilmu Indonesia, 2009), 183. 
mengkaji kembali kelemahan-kelemahan dari peraturan Mahkamah Agung sebelumnya, dengan tidak menghilangkan ciri dan asas mediasi tradisional yang telah ada dalam masyarakat Indonesia. Sistem mediasi yang bagaimana yang ingin dikembangkan, haruslah dikaji dalam relevansinya dengan sistem yang sudah ada dan dikenal di Indonesia.

Mahkamah Agung mengeluarkan Perma No. 1 tahun 2016 sebagai upaya mempercepat, mempermurah dan mempermudah proses penyelesaian sengketa serta memberikan akses yang lebih besar kepada pencari keadilan. Mediasi merupakan instrumen efektif untuk mengatasi penumpukan perkara di pengadilan, dan sekaligus memaksimalkan fungsi lembaga pengadilan dalam menyelesaikan sengketa, di samping proses pengadilan yang bersifat memutus.10

Kehadiran Perma No. 1 tahun 2016 dimaksudkan untuk memberikan kepastian, ketertiban, kelancaran dalam proses mendamaikan para pihak untuk menyelesaikan suatu sengketa perdata. Hal ini dapat dilakukan dengan mengoptimalkan fungsi lembaga peradilan dalam penyelesaian sengketa dan memenuhi kebutuhan pelaksanaan mediasi yang lebih berdayaguna dan mampu meningkatkan keberhasilan mediasi di pengadilan .11

Mediasi mendapatkan kedudukan penting dalam Perma No. 1 tahun 2016, karena proses mediasi merupakan bagian yang tidak terpisahkan dari proses berperkara di pengadilan. Para pihak wajib mengikuti prosedur penyelesaian sengketa melalui mediasi. Bila para pihak melanggar atau enggan menerapkan prosedur mediasi, maka gugatan dinyatakan tidak dapat diterima oleh hakim pemeriksa perkara dan dikenai pula kewajiban pembayaran biaya mediasi (pasal 22 ayat 1 dan ayat 2 ).

Akan tetapi, dalam kenyataannya, jarang dijumpai putusan perdamaian walaupun kedudukan hukum mediasi sudah sangat jelas ditambah dengan budaya masyarakat Indonesia yang memiliki watak suka bermusyawarah dalam menghadapi sengketa. Fakta menunjukkan, bahwa masyarakat dan tentu juga pengadilan belum memanfaatkan prosedur proses mediasi ini seoptimal mungkin.

10 Ibid., 302.

11 Mahkamah Agung RI, PERMARI No. 1 Tahun 2016 Tentang Prosedur Mediasi

Di Pengadilan MA RI. 
Achmad Syaifuddin: Studi Komparasi Efektivitas Perma...

Dalam upaya mengoptimalkan mediasi sebagai sarana penyelesaian sengketa perdata, para hakim di Pengadilan Agama Sidoarjo sudah seharusnya selalu mengupayakan dua pihak yang bersengketa untuk menempuh jalur damai, karena jalur damai akan mempercepat penyelesaian sengketa. Mediasi juga perlu dimaksimalkan penerapannya karena pada prinsipnya suatu peraturan dibuat untuk dijalankan, demikian juga halnya dengan Perma No. 1 tahun 2016 tentang prosedur mediasi di pengadilan .

Dalam perkara perdata, khususnya di wilayah Pengadilan Agama Sidoarjo, pada tahun 2015 menggunakan Perma No. 1 tahun 2008, jumlah pengajuan perceraian sejumlah 1.061. Sedangkan untuk tahun 2016 menggunakan Perma No.1 tahun 2016, jumlah pengajuan meningkat menjadi 4.471 perkara dan tahun 2017 bulan Juni mencapai 2.151.12 Perkara mediasi menempati posisi yang dominan sebagai upaya penyelesaian sengketa guna memudahkan hakim untuk menetapkan dan memutuskan suatu perkara, baik sengketa waris, waqaf, ataupun perkawinan. Karenaya, penulis tertarik mengkaji pelaksanaan mediasi oleh mediator di Pengadilan Agama Sidoarjo.

Penelitian sebelumnya pernah dilakukan oleh Aini Rahmawatik, berjudul Peran Mediator dalam Menyelesaikan Perkara Nomor, 98/Pdt.G/2009/PA.SBY. tentang Cerai Gugat di Pengadilan Agama Surabaya (Perspektif Perma Nomor 1 Tabun 2008)”. Kajian Aini ini menunjukan, bahwa peran mediator pada perkara cerai gugat sangatlah penting, dan ini terlihat ketika mediator menyelenggarakan upaya damai melalui proses mediasi di Pengadilan Agama Surabaya yaitu pada salah satu kasus cerai gugat dengan No. 98/Pdt.G/2009/PA.SBY. Dalam menjalankan tugasnya sebagai mediator, mediator perlu memperhatikan peran-perannya sebagai mediator yang ditinjau dari Perma No. 1 tahun 2008.

Sedangkan skripsi yang ditulis oleh Marjudi yang berjudul: Fungsi Mediator dalam Mengoptimalkan Perdamaian Harta Bersama di Pengadilan Agama Kabupaten Kediri dalam Tinjauan Peraturan Mabkamah Agung RI No. 2 Tabun 2003, menunjukkan, bahwa para mediator menyambut baik dengan dikeluarkannya Perma No. 2 tahun 2003

12 Zaenal Abidin, Wawancara, Sidoarjo, 7 juni 2017. 
yang membantu mediator dalam menangani perdamaian harta bersama, serta fungsi-fungsi mediatornya pun menjadi jelas dan terperinci di Pengadilan Agama Kabupaten Kediri.

Sedangkan kajian penulis terfokus pada efektifitas peraturan mahkamah agung tentang prosedur mediasi terhadap peran mediator di Pengadilan Agama Sidoarjo". Skripsi yang ditulis oleh Marjudi dan Aini Rahmawatik, memiliki persamaan, yakni meneliti tentang mediator dan mediasi atau upaya perdamaian di lingkup Peradilan Agama. Penelitian yang ditulis oleh Marjudi menekankan pada pembahasan fungsi mediator dalam menangani perdamaian harta bersama yang ditinjau dari Perma RI No. 2 Tahun 2003 di Pengadilan Agama Kabupaten Kediri, dan penelitian yang ditulis oleh Aini Rahmawatik fokus pada peranan mediator di Pengadilan Agama Surabaya pada kasus cerai gugat dengan No. 98/Pdt.G/2009/PA.SBY. yang ditinjau dari Perma RI Nomor 1 Tahun 2008.

\section{Pengertian Mediasi}

Dalam kamus besar Bahasa Indonesia, kata mediasi berarti proses pengikutsertaan pihak ketiga dalam penyelesaian suatu perselisihan sebagai penasehat.13 Pengertian mediasi yang diberikan kamus Bahasa Indonesia mengandung 3 unsur penting: Pertama, mediasi merupakan proses penyelesaian perselisihan atau sengketa yang terjadi antar dua pihak atau lebih. Kedua, pihak yang terlibat dalam penyelesaian sengketa adalah pihak-pihak yang berasal dari luar pihak yang bersengketa. Ketiga, pihak yang terlibat dalam penyelesaian sengketa tersebut bertindak sebagai penasehat dan tidak memiliki kewenangan apa-apa dalam pengambilan keputusan.

J. Folberg dan A. Taylor lebih menekankan konsep mediasi pada upaya yang dilakukan mediator dalam menjalankan kegiatan mediasi.14 Kedua ahli ini menyatakan, bahwa penyelesaian sengketa

13 Tim Penyusun Kamus Pusat Pembinaaan dan Pengembangan Bahasa, Kamus Besar Bahasa Iindonesia (Jakarta: departemen pendidikan dan kebudayaan, 1988), 569.

14 Syahrizal Abbas, Mediasi dalam Hukum Syariah, Hukum adat, dan Hukum Nasional (Jakarta: Kencana Prenada Media Group, 2011), 5., sebagaimana dikutip dari Folberg dan A. Taylor: Mediation: A Comperhensive Guide to Resolving Conflict without Litigation (Cambridge: Cambridge University Press 1884), 7. 
melalui jalur mediasi dilakukan secara bersama-sama oleh pihak yang bersengketa dan dibantu oleh pihak yang netral. Mediator dapat mengembangkan dan menawarkan pilihan penyelesaian sengketa dan para pihak dapat pula mempertimbangkan tawaran mediator sebagai suatu alternatif menuju kesepakatan dalam penyelesaian sengketa.15

Menurut Garry Goopaster, mediasi merupakan proses negoisasi pemecahan masalah di mana pihak luar yang tidak memihak (imparsial) bekerja sama dengan pihak-pihak yang bersengketa untuk membantu mereka memperoleh kesepakatan perjanjian yang memuaskan.16 Garry Goopaster memberikan pendapat tentang mediasi tidak hanya terbatas pada pengertian bahasa, melainkan gambar keseluruhan terkait proses kegiatan mediasi, serta tujuan dilakukannya mediasi tersebut. Dia menekankan, bahwa mediasi adalah proses negoisasi di mana pihak ketiga melakukan dialog dengan pihak yang bersangkutan dan mencoba mencari kemungkinan penyelesaian dari sengketa yang dimaksudkan.

Pengertian mediasi dapat ditemukan di Perma No. 1 Tahun 2016 Tentang Prosedur Mediasi: Mediasi adalah cara penyelesaian sengketa melalui proses perundingan untuk memperoleh kesepakatan para pibak dengan dibantu oleh mediator (Pasal 1 butir 1). Mediator adalah bakim atau pibak. lain yang memiliki sertifikat mediator sebagai pibak netral yang membantu para pibak dalam proses perundingan guna mencari berbagai kemungkinan penyelesaian sengketa tanpa menggunakan cara memutus atau memaksakan sebuah penyelesain (Pasal 1 butir 2).

Pengertian mediasi menurut Perma No. 1 tahun 2016 tidak jauh berbeda dengan esensi mediasi yang dikemukakan oleh beberapa pakar tersebut. Namun, pengertian ini menekankan pada satu aspek penting, yaitu mediator dituntut proaktif untuk mencari berbagai kemungkinan penyelesaian sengketa. Beberapa unsur penting dalam mediasi antara lain sebagai berikut:

1. Mediasi adalah proses penyelesaian sengketa berdasarkan perundingan

15 Ibid.

16 Garry Goopaster, Negoisasi dan Mediasi: Sebuab Pedoman Negoisasi dan Penyelesaian Sengketa Melalui Negoisasi (Jakarta: ELIPS Project. 1993), 201. 
2. Mediator terlibat dan diterima para pihak yang bersengketa di dalam perundingan

3. Mediator bertugas membantu para pihak yang bersengketa untuk mencari penyelesaian.

4. Mediator tidak mempunyai kewenangan membuat keputusan selama perundingan berlangsung.

5. Tujuan mediasi adalah untuk mencapai atau menghasilkan kesepakatan yang diterima pihak-pihak yang bersengketa guna mengakhiri sengketa.17

\section{Landasan Hukum Mediasi dalam Islam dan Hukum Positif}

Dalam upaya perdamaian, tahap pertama yang harus dilakukan oleh hakim dalam menyidangkan perdamaian kepada pihak-pihak yang bersengketa adalah mengadakan perdamaian kepada pihak-pihak yang bersengketa. Kewajiban hakim dalam mendamaikan pihak-pihak yang berperkara adalah sejalan dengan tuntunan ajaran Islam. Ajaran Islam memerintahkan agar menyelesaikan setiap perselisihan yang terjadi di antara manusia sebaiknya dengan jalan perdamaian (islab). Ketentuan ini sejalan dengan firman Allah SWT dalam al-Quran Surah al-Hujurat Ayat 25 yang artinya: Sesunggubnya orang-orang mukmin adalah bersaudara karena itu damaikanlah antara kedua saudaramu dan bertakwalah kepada Allah supaya kamu mendapat rabmat.18

Dari ayat tersebut dapat dipahami, bahwa jika dua golongan orang beriman bertengkar maka damaikanlah mereka, perdamaian itu hendaklah dilakukan dengan adil dan benar sebab Allah sangat mencintai orang yang berlaku adil.19

Adapun landasan hukum dalam penerapan mediasi di Indonesia diantaranya:

1. HIR Pasal 130 dan Rbg Pasal 154 telah mengatur lembaga perdamaian. Hakim wajib terlebih dahulu mendamaikan para pihak yang berperkara sebelum perkaranya diperiksa.

17 Suyut Margono, ADR dan Arbitrase Proses Pelembagaan dan Aspek Hukum (Bogor: PT.Graha Indonesia, 2000), 59.

18 Q.S. Surah Al-Hujurat: 9.

19 Abdul Manan, Penerapan Hukum Acara Perdata di Lingkungan Peradilan Agama (Jakarta: Kencana Prenada Media, 2005), 151. 
Achmad Syaifuddin: Studi Komparasi Efektivitas Perma...

2. SEMA No. 1 Tahun 2002 Tentang Pemberdayaan Lembaga Perdamaian Dalam Pasal 130 HIR/154 Rbg.

3. Perma No. 2 Tahun 2003 Tentang Prosedur Mediasi Di Pengadilan.

4. Perma No. 1 Tahun 2008 Tentang Prosedur Mediasi Di Pengadilan.

5. Mediasi atau Alternatif Penyelesaian Sengketa di luar Pengadilan diatur dalam Pasal 6 UU Nomor 30 tahun 1999 tentang Arbitrase dan Alternatif Penyelesaian Sengketa.

\section{Tujuan dan Manfaat Mediasi.}

Sebagaimana umumnya lembaga alternatif penyelesaian sengketa yang lain, maka tujuan dan manfaat mediasi masih terkait dengan karakteristik umum keunggulan dan manfaat yang terdapat pada alternatif penyelesaian sengketa, antara lain yaitu:

1. Relatif lebih murah dibandingkan dengan alternatif-alternatif yang lain

2. Adanya kecenderungan dari pihak yang bersengketa untuk menerima dan adanya rasa memiliki putusan mediasi

3. Dapat menjadi dasar bagi pihak yang bersengketa untuk menegosiasikan sendiri sengketa-sengketa yang mungkin timbul di kemudian hari.

4. Terbukanya kesempatan untuk menelaah masalah-masalah yang merupakan dasar dari suatu sengketa

5. Membuka kemungkinan adanya saling percaya di antara pihak yang bersengketa sehingga dapat dihindari rasa permusuhan dan dendam.20

6. Dalam pelaksanaan mediasi, segala hal yang diungkap serta sifat acara mediasi adalah rahasia. Berbeda dengan acara litigasi yang sifatnya terbuka untuk umum. Sifat tidak terbuka untuk umum ini bisa membuat pihak-pihak yang bersengketa merasa nyaman selama pelaksanaan mediasi dalam rangka penyelesaian sengketa. Karena tanpa adanya kekhawatiran sengketa yang terjadi di antara mereka menjadi perhatian publik.

20 Munir Fuady, Arbitrase Nasional: Alternative Penyelesaian Sengketa Bisnis (Bandung: PT. Citra Aditya Bakti: 2005), 50. 
7. Penyelesaian melalui mediasi mempersingkat waktu penyelesaian berperkara, memperingan beban ekonomi keuangan, dan yang tidak kalah penting adalah mengurangi beban psikologis yang akan mempengaruhi berbagai sikap dan kegiatan pihak yang berperkara. 21

8. Salah satu manfaat mediasi apabila dilihat dari kekuatan putusan yang dihasilkan adalah terselesaikannya sengketa dengan damai, karena pada hakekatnya mekanisme mediasi adalah upaya untuk mengarahkan para pihak yang bersengketa agar menyelesaikan sengketa yang terjadi dengan perdamaian. Kekuatan hukum mediasi tidak jauh berbeda dengan kekuatan akta perdamian. Putusan perdamaian hasil mediasi mempunyai kekuatan eksekutorial sebagaimana putusan yang dihasilkan dari persidangan (proses litigasi).

9. Apabila sudah tercapai kesepakatan para pihak, maka hakim membuatkan amar putusan menjatuhkan putusan sesuai dengan isi persetujuan dictum (amar): menghukum para pihak untuk menaati dan melaksanakan isi persetujuan perdamaian. Amar putusan selanjutnya adalah "menghukum para pihak membayar biaya perkara dengan ditanggung masing-masing pihak secara sama besar".

10.Bagi Mahkamah Agung, apabila mediasi di pengadilan bisa terlaksana dengan baik, maka hal itu akan mengurangi tumpukan perkara yang harus diselesaikan oleh Mahkamah Agung.

11.Pemberdayaan individu. Orang yang menegosiasikan sendiri masalahnya sering kali merasa mempunyai lebih banyak kuasa daripada mereka yang melakukan advokasi melalui wakil seperti pengacara.

\section{Proses Mediasi}

Tahap pra-mediasi adalah tahap para pihak mendapatkan tawaran dari hakim untuk menggunakan jalur mediasi dan para pihak menunjuk mediator sebagai pihak ketiga yang akan membantu menyelesaikan sengketa mereka.

21 Bagir Manan, Mediasi Sebagai Alternative Menyelesaikan Sengketa, Majalah Hukum Varia Peradilan, No. 24 (8 juli 2006), 9. 
Achmad Syaifuddin: Studi Komparasi Efektivitas Perma...

Konvach membagi proses mediasi ke dalam sembilan tahapan, yakni sebagai berikut:22

1. Penataan atau pengaturan awal

2. Pengantar atau pembukaan oleh mediator

3. Pernyataan pembukaan oleh para pihak

4. Pengumpulan informasi

5. Identifikasi masalah-masalah, penyusunan agenda dan kaukus

6. Membangkitkan pilihan-pilihan pemecahan

7. Melakukan tawar-menawar

8. Kesepakatan

9. Penutup

Perma No. 01 tahun 2008 berisi tahap pra-mediasi. sedangkan tahap proses mediasi ada dalam Perma No. 01 tahun 2008 Pasal 1 ayat (9) sebagai berikut:23

1. Tahap pra mediasi

a. Pada hari sidang yang telah ditentukan yang dihadiri kedua belah pihak, hakim mewajibkan para pihak untuk menempuh mediasi.

b. Ketidakhadiran pihak turut tergugat tidak menghalangi pelaksanaan mediasi.

c. Hakim, melalui kuasa hukum atau langsung kepada para pihak, mendorong para pihak untuk berperan langsung atau aktif dalam proses mediasi.

d. Kuasa hukum para pihak berkewajiban mendorong para pihak sendiri ber[eran langsung atau aktif dalam proses mediasi.

e. Hakim wajib menunda proses persidangan perkara untuk memberikan kesempatan kepasa para pihak menempuh proses mediasi.

f. Hakim wajib menjelaskan prosedur mediasi dalam PERMAkepada para pihak.

2. Tahap-tahap proses mediasi.

a. Dalam waktu paling lama 5 (lima) hari kerja setelah para pihak menunjuk mediator yang disepakati, masing-masing pihak dapat menyerahkan resume perkara kepada satu sama lain dan kepada mediator.

22 Suyud Margono, Alternative Dispute Resolution dan Abritase..., 63.

23 M. Yahya Harahap, Hukum Acara Perdata, Cet, VIII..., 247. 
b. Dalam waktu paling lama 5 (lima) hari kerja setelah para pihak gagal memilih mediator, masing-masing pihak dapat menyerahkan resume perkara kepada mediator yang ditunjuk.

c. Proses mediasi berlangsung paling lama 40 (empat puluh) hari kerja sejak mediator dipilih oleh para pihak atau ditunjuk oleh ketua mejelis hakim sebagaimana dimaksud dalam pasal 11 ayat (5) dan (6).

d. Atas dasar kesepakatan para pihak, jangka waktu mediasi dapat diperpanjang paling lama 14 (empat belas) hari kerja sejak berakhir masa 40 (empat puluh) hari kerja sejak berakhir masa 40 (empat puluh) hari sebagimana dimaksud dalam ayat 3.

e. Jangka waktu proses mediasi tidak termasuk jangka waktu pemeriksaan perkara.

f. Jika diperlukan dan atas dasar kesepkatan para pihak, mediasi dalapat dilakukan secara jarak jauh dengan menggunakan alat komunikasi.24

\section{Perbedaan Perma No.1 Tahun 2008 dan Perma No. 1 Tahun 2016}

Terbitnya Perma No.1 tahun 2016 tentang prosedur mediasi di Pengadilan disambut baik oleh Asosiasi Pengacara Syariah Indonesia (APSI). Pengelola Pusdiklat APSI, Thalis Noor Cahyadi, mengatakan, bahwa ada beberapa hal penting yang menjadi pembeda antara Perma No. 1 tahun 2016 dengan Perma No. 1 tahun 2008 tentang mediasi.25Pertama, terkait batas waktu mediasi yang lebih singkat dari 40 hari menjadi 30 hari terhitung sejak penetapan perintah melakukan mediasi. Kedua, adanya kewajiban bagi para pihak (inpersoon) untuk menghadiri secara langsung pertemuan mediasi dengan atau tanpa didampingi oleh kuasa hukum, kecuali ada alasan sah seperti kondisi kesehatan yang tidak memungkinkan hadir dalam pertemuan mediasi berdasarkan surat keterangan dokter; di bawah pengampuan; mempunyai tempat tinggal, kediaman atau kedudukan di luar negeri; atau menjalankan tugas

24 Perma No. 01 Tahun 2008 Tentang Prosedur Mediasi Di Pengadilan.

25 Sumber: http://www.hukumonline.com/berita/baca/lt56bb2d4541fd5/inipoin-penting-yang-diatur-dalam-perma-no1-tahun-2016, di akses pada 7-Juni2017. 
negara, tuntutan profesi atau pekerjaan yang tidak dapat ditinggalkan.

Ketiga, hal yang paling baru adalah adanya aturan tentang Iktikad Baik dalam proses mediasi dan akibat hukum para pihak yang tidak beriktikad baik dalam proses mediasi. Pasal 7 menyatakan:

(1) Para Pihak dan/atau kuasa hukumnya wajib menempuh Mediasi dengan iktikad baik. 2) Salah satu pihak atau para pihak dan/atau kuasa hukumnya dapat dinyatakan tidak beriktikad baik oleh Mediator dalam hal yang bersangkutan:26

1. tidak hadir setelah dipanggil secara patut 2 (dua) kali berturut-turut dalam pertemuan Mediasi tanpa alasan sah;

2. menghadiri pertemuan Mediasi pertama, tetapi tidak pernah hadir pada pertemuan berikutnya meskipun telah dipanggil secara patut 2 (dua) kali berturut-turut tanpa alasan sah;

3. ketidakhadiran berulang-ulang yang mengganggu jadwal pertemuan Mediasi tanpa alasan sah;

4. menghadiri pertemuan Mediasi, tetapi tidak mengajukan dan/atau tidak menanggapi Resume Perkara pihak lain; dan/atau

5. tidak menandatangani konsep Kesepakatan Perdamaian yang telah disepakati tanpa alasan sah.

Apabila penggugat dinyatakan tidak beriktikad baik dalam proses Mediasi sebagaimana dimaksud dalam Pasal 7 ayat (2), maka berdasarkan Pasal 23, gugatan dinyatakan tidak dapat diterima oleh hakim pemeriksa perkara. Hal ini ditegaskan dalam Pasal 22 Perma No.1 tahun 2016.

Penggugat yang dinyatakan tidak beriktikad baik sebagaimana dimaksud pada ayat (1) dikenai pula kewajiban pembayaran biaya mediasi. Mediator menyampaikan laporan penggugat tidak beriktikad baik kepada hakim pemeriksa perkara disertai rekomendasi pengenaan biaya mediasi dan perhitungan besarannya dalam laporan ketidakberhasilan atau tidak dapat dilaksanakannya mediasi.

26 Perma No.1 Tahun 2016 Tentang Prosedur Mediasi. 
Berdasarkan laporan mediator sebagaimana dimaksud pada ayat (3), Hakim pemeriksa perkara mengeluarkan putusan yang merupakan putusan akhir yang menyatakan gugatan tidak dapat diterima disertai penghukuman pembayaran Biaya mediasi dan biaya perkara.

Biaya mediasi sebagai penghukuman kepada penggugat dapat diambil dari panjar biaya perkara atau pembayaran tersendiri oleh penggugat dan diserahkan kepada tergugat melalui kepaniteraan Pengadilan. Apabila Tergugat yang dinyatakan tidak beriktikad baik sebagaimana dimaksud dalam Pasal 7 ayat (2), dikenai kewajiban pembayaran biaya mediasi. Mediator menyampaikan laporan tergugat tidak beriktikad baik kepada hakim pemeriksa perkara disertai rekomendasi pengenaan biaya mediasi dan perhitungan besarannya dalam laporan ketidakberhasilan atau tidak dapat dilaksanakannya Mediasi.

Berdasarkan laporan Mediator sebagaimana dimaksud pada ayat (2), sebelum melanjutkan pemeriksaan, hakim pemeriksa perkara dalam persidangan yang ditetapkan berikutnya wajib mengeluarkan penetapan yang menyatakan tergugat tidak beriktikad baik dan menghukum tergugat untuk membayar biaya mediasi.

Biaya mediasi sebagaimana dimaksud pada ayat (3) merupakan bagian dari biaya perkara yang wajib disebutkan dalam amar putusan akhir. Dalam hal tergugat sebagaimana dimaksud pada ayat (1) dimenangkan dalam putusan, amar putusan menyatakan biaya mediasi dibebankan kepada tergugat, sedangkan biaya perkara tetap dibebankan kepada penggugat sebagai pihak yang kalah.

Dalam perkara perceraian di lingkungan peradilan agama, tergugat sebagaimana dimaksud pada ayat (1) dihukum membayar biaya mediasi, sedangkan biaya perkara dibebankan kepada penggugat. Pembayaran biaya mediasi oleh tergugat yang akan diserahkan kepada penggugat melalui kepaniteraan pengadilan mengikuti pelaksanaan putusan yang telah berkekuatan hukum tetap. Dalam hal para pihak secara bersama-sama dinyatakan tidak beriktikad baik oleh mediator, gugatan dinyatakan tidak dapat diterima oleh hakim pemeriksa perkara tanpa penghukuman biaya mediasi. 


\section{Mediator Pada Proses Mediasi di Pengadilan Agama Sidoarjo}

Prosedur Mediasi di Pengadilan Agama Sidoarjo merupakan proses yang akan menghasilkan keberhasilan dalam menyelesaikan sengketa di bidang perdata yang lebih berkualitas. Dalam pelaksanaan proses mediasi, pasti ada sebuah prosedur yang menjadi pedoman dalam pelaksanaan mediasi, terutama seorang mediator. Siti Aisyah, salah satu mediator hakim di Pengadilan Agama Sidoarjo mengatakan, kaitannya dengan peran mediator dalam menyelesaikan sengketa perkara perdata, para mediator harus mempunyai pedoman dalam menyelesaian perselisihan, yakni dengan hukum materiil dan peraturan prosedur mediasi di pengadilan. 27

Sebagaimana yang tercantum dalam peraturan Mahkamah Agung Nomor 1 tahun 2016 revisi dari Perma No. 1 tahun 2008 tentang prosedur mediasi di pengadilan. Pedoman dalam menyelesaikan sengketa yang diterapkan Pengadilan Agama Sidoarjo yang awalnya menggunakan Perma No. 1 tahun 2008 tentang prosedur mediasi di pengadilan, seiring dengan terbitnya Perma No. 1 tahun 2016 tentang prosedur mediasi, ada beberpa point perbedaan, yakni: Pertama, terkait batas waktu mediasi yang lebih singkat dari 40 hari menjadi 30 hari terhitung sejak penetapan perintah melakukan mediasi. Kedua, adanya kewajiban bagi para pihak (inpersoon) untuk menghadiri secara langsung pertemuan mediasi dengan atau tanpa didampingi oleh kuasa hukum, kecuali ada alasan sah seperti kondisi kesehatan yang tidak memungkinkan hadir dalam pertemuan mediasi berdasarkan surat keterangan dokter; di bawah pengampuan; mempunyai tempat tinggal, kediaman atau kedudukan di luar negeri; atau menjalankan tugas negara, tuntutan profesi. Ketiga, hal yang paling baru adalah adanya aturan tentang Iktikad Baik dalam proses mediasi dan akibat hukum para pihak yang tidak beriktikad baik dalam proses mediasi. Pasal 7 menyatakan: (1) Para Pihak dan/atau kuasa hukumnya wajib menempuh mediasi dengan iktikad baik. 2) Salah satu pihak atau para pihak dan/atau kuasa hukumnya dapat dinyatakan tidak beriktikad baik oleh mediator. Apabila penggugat dinyatakan tidak beriktikad baik dalam proses mediasi sebagaimana dimaksud dalam

27 Siti Aisyah, Wawancara, Sidoarjo, 6 Juni 2017. 
Pasal 7 ayat (2), maka berdasarkan Pasal 23, gugatan dinyatakan tidak dapat diterima oleh hakim pemeriksa perkara. Hal ini ditegaskan dalam Pasal 22 Perma No.1 tahun 2016.

Penggugat yang dinyatakan tidak beriktikad baik sebagaimana dimaksud pada ayat (1) dikenai pula kewajiban pembayaran biaya mediasi. Mediator menyampaikan laporan penggugat tidak beriktikad baik kepada hakim pemeriksa perkara disertai rekomendasi pengenaan biaya mediasi dan perhitungan besarannya dalam laporan ketidakberhasilan atau tidak dapat dimediasi.

Siti Aisyah selaku Mediator di Pengadilan Agama Sidoarjo, mengatakan adapun prosedur mediasi yang selama ini dilakukan yakni:28

1. Tahap pra-mediasi

a. Dalam mengajukan perkara perdata di Pengadilan Agama Sidoarjo, pada hari sidang tahap pertama yang harus dilakukan ialah wajib menempuh proses mediasi dalam menyelesaikan suatu sengketa.

b. Majelis hakim pemeriksa perkara kemudian segera menentukan mediator hakim untuk menjadi mediator dalam pelaksanaan mediasi tersebut. Alasan ditentukannya mediator oleh majelis hakim Pengadilan Agama Sidoarjo, karena proses ini dianggap lebih cepat daripada menunggu para pihak memilih mediator dengan sendirinya, dengan ketentuan para pihak juga menyetujuinya. Dalam proses mediasi yang dilaksanakan di Pengadilan Agama Sidoarjo, selama ini menggunakan mediator dari kalangan hakim Pengadilan Agama Sidoarjo dan tidak pernah menggunankan mediator dari luar atau disebut dengan mediator non-hakim sebagai fasilitator para pihak bersengketa untuk menyelesaikan suatu perselisihan.

c. Mediator menentukan hari dan tanggal pertemuan mediasi, setelah menerima penetapan penunjukan mediator, pihak Peradilan AgamaS idoarjo melakukan pemanggilan para pihak untuk menghadiri pertemuan mediasi.

28 Siti Aisyah, Wawancara, Sidoarjo 6 Juni 2017. 
d. Apabila para pihak hadir dalam sidang pertemuan pertama, maka proses mediasi rata-rata dilakukan dalam jangka dua minggu sekali atau satu kali dilaksanakan, hal ini dikarenakan para pihak sudah bersikukuh untuk mengkomunikasikan masalah mereka bersama-sama. Namun jika tergugat tidak hadir, maka mediator meminta bantuan hakim pemeriksa perkara untuk memanggil secara patut dengan bantuan juru sita pengadilan, supaya para pihak tersebut hadir pada waktu dan tempat yang telah ditentukan. Jika setelah dilakukan dua kali pemanggilan secara patut, pihak tersebut tidak hadir tanpa alasan yang sah, maka mediator wajib untuk menyatakan, bahwa proses mediasinya telah gagal. Lain halnya dengan pihak yang tidak pernah hadir kemudian pada sidang kedua waktu pembuktian hadir maka mediasi tetap dilakukan pada tiap tahapan pemeriksaan perkara, hakim pemeriksa perkara tetap berwenang untuk mengusahakan perdamaian hingga sebelum pengucapan putusan.

e. Para pihak wajib menempuh proses mediasi dengan iktikad baik, apabila salah satu pihak tidak beritikad baik maka dinyatakan mundur dari proses mediasi.

Panitera Pengadilan Agama Agama mengatakan bahwa pada perkara tersebut telah berlangsung lama yang sebelumnya sudah pernah dicoba diselesaikan secara kekeluargaan, namun gagal untuk ditemui titik terang dan merasa jalan satu-satunya penyelesaian masalah mereka adalah melalui jalur litigasi. Sehingga pada saat dilakukan mediasi, para pihak terkesan kurang antusias dan enggan melakukan prosedur tersebut. 29

Ada juga para pihak yang pada awalnya terkesan mempunyai respon yang bagus saat hakim memerintahkan untuk dilakukan mediasi, namun pada pelaksanaannya sulit, terlebih-lebih jika hubungan personal d iantara mereka kurang harmonis. Ada pula pihak yang dari awal bersikukuh menolak untuk mediasi, mereka benar-benar tidak ada kemauan sama sekali untuk bersungguh-sungguh mengupayakan damai.

29 Zaenal Abidin, Wawancara, Sidoarjo, 9 Juni 2017. 
2. Tahapan proses mediasi

Dalam tahap proses mediasi ini apabila salah satu pihak telah dua kali berturut-turut tidak menghadiri pertemuan mediasi sesuai jadwal pertemuan mediasi yang telah disepakati, maka mediasi dinyatakan gagal. Jika mediasi menghasilkan kesepakatan perdamaian, para pihak dengan bantuan mediator wajib merumuskan secara tertulis kesepakatan yang dicapai dan ditandatangani oleh para pihak dan mediator. Zainal Abidin menjelaskan, bahwa mediator di Pengadilan Agama Sidoarjo menganggap mediasi sebagai bagian dari tugas wajib hakim sebagai orang yang bertugas menyelesaikan kasus yang masuk ke pengadilan.30 Bapak Zaenal pun berpendapat bahwa mediasi bertujuan menyelesaikan masalah/sengketa untuk mencapai kesepakatan yang menguntungkan pihak-pihak yang bersengketa sehingga dicapai hasil yang memuaskan.31

Lain halnya dengan pendapat Siti Aisyah, ia mengatakan, bahwa mediasi adalah amanah yang diemban oleh mediator untuk melakukan mediasi karena mereka menganggap sebagai sesuatu yang harus dipertanggungjawabkan sampai akhirat nanti, jadi harus dilakukan dengan sungguh-sungguh.32

Mediator memandang, bahwa mediasi merupakan kewajiban tugas yang harus dijalankan karena aturan hukumnya menetapkan demikian, meskipun itu merupakan tugas sampingan bukan termasuk tugas pokok, tetapi semuanya harus dilaksananakan dengan baik, sebab jika tidak dilakukan, maka akan mengakibatkan putusannya batal demi hukum.

Maka dari itu, mediasi harus dilakukan untuk menghindari batalnya sebuah putusan. Pengadilan bukan hanya sebagai lembaga yang menegakkan hukum dan keadilan, tetapi pengadilan juga bertugas sebagai lembaga yang mencari solusi antara pihak-pihak yang bersengketa.

Adapun rekapitulasi laporan mediasi di Pengadilan Agama Sidoarjo Tahun 2015-2017, yaitu, perkara yang dimediasi pada bulan Januari-Desember Tahun 2015 berjumlah 1.061 perkara.

30 Zainal Abidin, Wawancara, Sidoarjo 6 Juni 2017

31 Ibid.

32Siti Aisyah, Wawancara, Sidoarjo, 6 Juni 2017. 
Semua perkara mediasi yang masuk pada Tahun 2015 yang dinyatakan berhasil, ada 9 perkara. Sedangkan pada bulan Januari-Desember Tahun 2016, dari 4.471 perkara yang dinyatakan berhasil ada 26 perkara. Kemudian pada bulan Januari-Juni 2017, dari 2.151 perkara yang dinyatakan berhasil ada 5 perkara. 33

Dengan melihat rekapitulasi laporan mediasi ini disimpulkan, bahwa di Pengadilan Agama Sidoarjo masih minim mediasi. Dikatakan tidak berhasil pada dasarnya bukan karena kurangnya memaksimalkan prosedur proses mediasi sesuai dengan Perma tentang prosedur mediasi, baik pada Perma No. 1 tahun 2008 ataupun setelah menggunakan Perma No.1 tahun 2016, tetapi faktor yang paling mempengaruhi keberhasilan mediasi di pengadilan adalah niatan damai dari para pihak itu sendiri. Hal-hal inilah yang menyebabkan proses mediasi dikatakan berhasil atau gagal untuk menyelesaikan perkaranya melalui jalur damai dengan proses medasi.

\section{Studi Komparasi Efektifitas Perma No. 1 Tahun 2008 dan Perma No. 1 Tahun 2016 Tentang Prosedur Mediasi Terhadap Peran Mediator di Pengadilan Agama Sidoarjo}

Prosedur mediasi bukanlah suatu fenomena baru di Pengadilan Agama Sidoarjo, mediasi telah dilaksanakan setelah adanya Perma No. 1 tahun 2008. Tetapi pelaksanaannya belum maksimal, kesimpulan ini dilihat dari ungkapan wawancara panitera tentang prosedur mediasi di Pengadilan Agama Sidoarjo. Setelah direvisi menjadi Perma Nomor 1 tahun 2016, terbit tanggal 04 Februari 2016, diharapkan prosedur mediasi di Pengadilan Agama Sidoarjo lebih optimal lagi.

Menurut penjelasan pasal 38 Perma No. 1 tahun 2016 tentang prosedur mediasi di pengadilan, bahwa pada saat Peraturan Mahkamah Agung ini mulai berlaku, Perma No. 1 tahun 2008 tentang Prosedur Mediasi di Pengadilan dicabut dan dinyatakan tidak berlaku. Berdasarkan penjelasan peraturan tersebut dapat dipahami, bahwa pelaksanaan Perma No. 1 tahun 2016 mulai

33 http://www. pa-sidoarjo.go.id/, diakses pada 7 Juni 2017. 
diterapkan sebagai acuan dalam proses beracara mediasi di Pengadilan Agama.

Mediator hakim Pengadilan Agama Sidoarjo, dalam menyelesaikan perselisihan menggunakan Perma No. 1 Tahun 2008 sebagai acuan proses beracara mediasi di Pengadilan Agama Sidoarjo pada tahun 2015, perkara yang dimediasi pada bulan januari-desember Tahun 2015 berjumlah 1.061 perkara, yang dinyatakan berhasil ada 9 perkara.34 Kemudian dengan adanya revisi dari Perma No. 1 tahun 2008 ke Perma No. 1 tahun 2016 pada bulan Januari-Desember Tahun 2016, dari 4.471 perkara yang dinyatakan berhasil ada 26 perkara. Kemudian pada bulan Januari-Juni 2017, dari 2.151 perkara yang dinyatakan berhasil ada 5 perkara. Proses mediasi yang sesuai dengan aturan dalam Perma No. 1 tahun 2016 dilaksanakan sebelum perkara disidangkan. Hal ini sesuai dengan pasal 3 ayat 1 Perma No. 1 tahun 2016, yaitu tidak menempuh proses mediasi berdasarkan peraturan ini merupakan pelanggaran terhadap ketentuan pasal 130 HIR dan atau pasal 154 Rbg yang mengakibatkan putusan batal demi hukum.

Perbedaan pertama antara Perma No. 1 tahun 2008 ke Perma No. 1 tahun 2016 yaitu pada batas waktu mediasi yang lebih singkat dari 40 hari menjadi 30 hari terhitung sejak penetapan perintah melakukan Mediasi. Hal tersebut sangat membantu mediator di Pengadilan Agama Sidoarjo untuk lebih cepat melakukan proses mediasi setelah adanya Perma No. 1 tahun 2016.35

Kedua, adanya kewajiban bagi para pihak (inpersoon) untuk menghadiri secara langsung pertemuan Mediasi dengan atau tanpa didampingi oleh kuasa hukum, kecuali ada alasan sah seperti kondisi kesehatan yang tidak memungkinkan hadir dalam pertemuan mediasi berdasarkan surat keterangan dokter; di bawah pengampuan; mempunyai tempat tinggal, kediaman atau kedudukan di luar negeri; atau menjalankan tugas negara, tuntutan profesi. Mediator Pengadilan Agama Sidoarjo menganggap hal kedua ini sebagai revisi yang bisa menjadi penunjang keberlanjutan proses mediasi, karena tanpa adanya peraturan kewajiban pihak

34 Muhammad Jumhari, "Rekapitulasi Perkara" dalam http://www. Pasidoarjo.go.id/, di akses pada 7 Juni 2017.

35 Siti Aisyah, Wawancara, Sidoarjo, 6 Juni 2017. 
untuk menghadiri proses mediasi secara langsung, banyak pihak akan melewatkan atau tidak menghadiri proses mediasi tersebut.

Ketiga, hal yang paling baru adalah adanya aturan tentang iktikad baik dalam proses mediasi dan akibat hukum para pihak yang tidak beriktikad baik dalam proses mediasi. Pasal 7 menyatakan: (1) para pihak dan/atau kuasa hukumnya wajib menempuh mediasi dengan iktikad baik. (2) salah satu pihak atau para pihak dan/atau kuasa hukumnya dapat dinyatakan tidak beriktikad baik oleh mediator. Dalam hal ini, merupakan hal yang paling penting bagi mediator untuk memperlancar proses mediasi, karena dengan adanya itikad baik dari pihak yang akan melakukan proses mediasi, sangat membantu meningkatkan keberhasilan dalam proses mediasi yang kemudian apabila penggugat dinyatakan tidak beriktikad baik dalam proses mediasi, sebagaimana dimaksud dalam Pasal 7 ayat (2), maka berdasarkan Pasal 23, gugatan dinyatakan tidak dapat diterima oleh hakim pemeriksa perkara. Hal ini ditegaskan dalam Pasal 22 Perma No. 1 tahun 2016. Penggugat yang dinyatakan tidak beriktikad baik sebagaimana dimaksud pada ayat (1) dikenai pula kewajiban pembayaran biaya mediasi (Denda). Mediator menyampaikan laporan penggugat tidak beriktikad baik kepada hakim pemeriksa perkara.

Selanjutnya, mediator berperan sebagai fasilitator. Pengadilan Agama Sidoarjo, selama ini menggunakan mediator hakim untuk membantu menyelesaikan perkara. Seorang mediator di Pengadilan Agama Sidoarjo, memiliki keahlian khusus di bidang penyelesaian sengketa yang dibuktikan dengan sertifikat mediator. Hal tersebut dimaksudkan agar orang yang menjadi mediator, adalah orang-orang yang benar-benar memiliki keterampilan komunikasi dan teknikteknik perundingan yang memadai. Selain itu, seorang mediator juga harus dibekali kemampuan komunikasi yang baik serta mampu memotivasi orang lain yang sedang bersengketa.

Pengadilan Agama Sidoarjo setelah menerapkan peraturan Mahkamah Agung Nomor 1 tahun 2016. Untuk bisa memaksimalkan tingkat efektivitas Perma Nomor 1 Tahun 2016 Tentang Prosedur Mediasi di Pengadilan ini, mediasi harus dilakukan sesuai dengan maksud dan tujuan mediasi yang semestinya: "Menyelesaikan masalah atau sengketa untuk mencapai 
kesepakatan yang menguntungkan pihak-pihak yang bersengketa sehingga dicapai hasil yang memuaskan". 36

Pengadilan tidak hanya bertugas dan berwenang memeriksa, mengadili, dan menyelesaikan suatu perkara tetapi berwenang mendamaikan para pihak yang berperkara. Pengadilan yang selama ini terkesan sebagai lembaga yang menegakkan hukum dan keadilan, tetapi sekarang pengadilan juga menampakkan diri sebagai lembaga yang mencari solusi antara pihak-pihak yang bertikai.

Adanya Perma No. 1 tahun 2016 ini cukup membantu kinerja mediator dalam menjalankan proses mediasi, tetapi tidak menambah jumlah keberhasilan mediasi yang signifikan, karena itikad baik dari peserta mediasi menjadi faktor utamanya.

\section{Penutup}

Mediator di Pengadilan Agama Sidoarjo selama ini berperan sebagai fasilitator untuk membantu menyelesaikan masalah atau sengketa untuk mencapai kesepakatan yang menguntungkan pihakpihak yang bersengketa sehingga dicapai hasil yang memuaskan. Seorang mediator di Pengadilan Agama Sidoarjo memiliki keahlian khusus di bidang penyelesaian sengketa yang berlandaskan dengan Perma No. 1 tahun 2008 jo. Perma No. 1 tahun 2016 tentang Prosedur Mediasi.

Terdapat perbedaan antara Perma No. 1 tahun 2008 dengan Perma No. 1 tahun 2016, yaitu mengenai batas waktu mediasi yang lebih singkat, adanya kewajiban bagi para pihak untuk menghadiri secara langsung pertemuan mediasi, dan adanya aturan tentang iktikad baik dalam proses mediasi serta akibat hukumnya. Perbedaan tersebut cukup membantu melancarkan proses keberlangsungan mediasi, tetapi tidak ada perubahan keberhasilan yang siginifikan terhadap pencegahan terjadinya perceraian, karena tidak adanya iktikad baik dari para pihak yang berperkara.

\section{Daftar Pustaka}

Abdul Manan, Penerapan Hukum Acara Perdata di Lingkungan Peradilan Agama, Jakarta: Kencana Prenada Media, 2005.

Bagir Manan, 'Mediasi Sebagai Alternative Menyelesaikan Sengketa', Majalah Hukum Varia Peradilan, No. 24 (8 juli 2006.

36Zaenal Abidin, Wawancara, Sidoarjo, 9 Juni 2017. 
Achmad Syaifuddin: Studi Komparasi Efektivitas Perma...

Bambang Sutiyoso, Alternatif Penyelesaian Sengketa, Yogyakarta: Gama Mediasi, 2008.

Garry Goopaster, Negoisasi dan Mediasi: Sebuah Pedoman Negoisasi dan Penyelesaian Sengketa Melalui Negoisasi, Jakarta: ELIPS Project. 1993.

M. Yahya Harahap, Hukum Acara PERD ATA, Cet, VIII..., 247.

Maria S.W, et al., Mediasi Sengketa Tanah, Jakarta: KOMPAS Media Nusantara, 2008.

Muhammad Jumhari, "Rekapitulasi Perkara" dalam http://www. Pa-sidoarjo.go.id/, di akses pada 7 Juni 2017.

Munir Fuady, Arbitrase Nasional: Alternative Penyelesaian Sengketa Bisnis, Bandung: PT. Citra Aditya Bakti: 2005.

Sarwono, Hukum Acara Perdata Teori dan Praktik, Jakarta: Sinar Grafika,2011.

Siti Aisyah, Wawancara, Sidoarjo 6 Juni 2017.

Susanti Adi Nugroho, Mediasi Sebagai Alternatif Penyelesaian Sengketa, Jakarta: PT. Telaga Ilmu Indonesia, 2009.

Suyut Margono, ADR dan Arbitrase Proses Pelembagaan dan Aspek Hukum, Bogor: PT.Graha Indonesia, 2000.

Syahrizal Abbas, Mediasi dalam Perspektif Hukum Syariah, Hukum Adat, dan Hukum Nasional, Jakarta: Kencana, 2009.

Tim Penyusun Kamus Pusat Pembinaaan dan Pengembangan Bahasa, Kamus Besar Bahasa Indonesia, Jakarta: departemen pendidikan dan kebudayaan, 1988.

Yahya Harahap, Hukum Acara Perdata, Jakarta: Sinar Grafika, 2006. Zaenal Abidin, Wawancara, Sidoarjo, 7 juni 2017.

Zaenal Abidin, Wawancara, Sidoarjo, 9 Juni 2017.

Zainal Abidin, Wawancara, Sidoarjo 6 Juni 2017

http://www. Pa-sidoarjo.go.id/, diakses pada 7 Juni 2017.

Mahkamah Agung RI, Perma RI No. 1 Tahun 2008 Tentang Prosedur Mediasi di Pengadilan MA RI.

Perma No. 01 tahun 2008 tentang prosedur mediasi di Pengadilan. Perma No.1 tahun 2016 tentang prosedur mediasi.

http://www.hukumonline.com/berita/baca/lt56bb2d4541fd5/inipoin-penting-yang-diatur-dalam-perma-no1-tahun-2016, di akses pada 7-Juni-2017. 